\title{
O Eclesiastes de Adília, o de Camões
}

\author{
Luis Maffei \\ Universidade Federal Fluminense
}

\section{Resumo}

Dialogar com textos sagrados, a Bíblia sobretudo, participa ativamente da tradição da lírica ocidental, a portuguesa inclusive. O Novo e o Velho Testamento são fonte de diversas conversas propostas pela poesia portuguesa ao longo de seus diversos séculos de existência. Neste ensaio, serão contemplados dois diálogos que a poesia portuguesa propôs com o Antigo Testamento, um vindo de Camões, no século XVI, outro de Adília Lopes, no século XX. Camões e Adília têm, de modos singulares mas encontrados em muitas tangências, forte interesse pelo texto bíblico. Neste ensaio, a atenção recairá sobre como ele e ela convocaram o Eclesiastes para suas poéticas. Camões - autor, a propósito, de um soneto cujo incipit, "O dia que nasci moura e pereça", vem de Jó, outro livro bastante singular da Bíblia - lida com o texto assinado por certo Coélet espraiando algumas de suas postulações ao logo de sua obra, enquanto Adília escreveu um poema intitulado justamente "Eclesiastes", para o qual o conhecimento do livro bíblico é convocado. As ideias de sabedoria e vaidade são postas em causa pelo autor d'Os Lusíadas e pela erudita poetisa contemporânea, mas se encontram ainda mais as duas vozes, precisamente, numa ausência que, em verdade, é indelével, inelutável presença para ambos: Jesus Cristo, personagem que tudo altera no âmbito da religiosidade ocidental. Adília e Camões nutrem uma explícita paixão pelo apaixonado Cristo, problema que atravessa suas obras. Por isso, o Filho da Humanidade será, nos casos das duas poéticas que aqui se contempla, mediador da relação entre a poesia e o Antigo Testamento.

Palavras-chave: Bíblia; poesia portuguesa; Eclesiastes; Adília Lopes; Camões.

\section{The Ecclesiastes of Adília, of Camões}

\section{Abstract}

Many dialogs with sacred texts, Bible above all, were and are made by the tradition of western lyric, including Portuguese. The New and Old Testaments, for sure, are the source of several conversations proposed by Portuguese poetry throughout its several centuries of existence. In this essay, two dialogues that Portuguese poetry proposed with the Old Testament, one from Camões, in the 16th century, the other from Adilia Lopes, in the 20th century, will be contemplated. Camões and Adília have, in singular 
but sometimes similar ways, a strong interest in the biblical text. In this essay, attention will fall on how they and she summoned Ecclesiastes to their poetics. Camões - author, by the way, of a sonnet whose first line, "The day I was born Moorish and perish", comes from Job, another very unique book in the Bible - deals with the text signed by a certain Coélet spreading some of his postulations throughout her work, while Adília wrote a poem entitled "Ecclesiastes", for which the knowledge of the biblical book is summoned. The ideas of wisdom and vanity are called into question by the author of Os Lusíadas and by the erudite contemporary poet, but the two voices meet even more precisely in an absence that, in truth, is indelible, an inescapable presence for both: Jesus Christ, a character that changes everything in the scope of Western religiosity. Adília and Camões have an explicit passion for the passionate Christ, a problem that runs through their works. For this reason, the Son of Humanity will, in the cases of the two poetics contemplated here, mediate the relationship between poetry and the Old Testament.

Keywords: Bible; Portuguese poetry; Ecclesiastes; Adília Lopes; Camões.

\section{Lo Eclesiastés de Adília, lo de Camões}

\section{Resumen}

El diálogo con los textos sagrados, la Biblia sobre todo, participa activamente en la tradición de la lírica occidental, incluido el portugués. El Nuevo y Antiguo Testamento son fuente de varias conversaciones propuestas por la poesía portuguesa a lo largo de sus varios siglos de existencia. En este ensayo se contemplarán dos diálogos que la poesía portuguesa propuso con el Antiguo Testamento, uno de Camões, en el siglo XVI, el otro de Adília Lopes, en el siglo XX. Camões y Adília tienen, de formas singulares pero encontradas en muchas tangencias, un fuerte interés por el texto bíblico. En este ensayo, la atención se centrará en cómo él y ella convocaron a Eclesiastés a su poética. Camões autor, por cierto, de un soneto cuyo comienzo, "El día que nací moro y perecí", proviene de Job, otro libro muy singular de la Biblia, trata del texto firmado por un tal Collélet difundiendo algunas de sus postulaciones su obra, mientras que Adília escribió un poema titulado "Eclesiastés", para lo cual se invoca el conocimiento del libro bíblico. Las ideas de sabiduría y vanidad son cuestionadas por el autor de Os Lusíadas y por el erudito poeta contemporáneo, pero las dos voces se encuentran aún más precisamente en una ausencia que, en verdad, es indeleble, una presencia ineludible para ambos: Jesucristo, un personaje que lo cambia todo en el ámbito de la religiosidad occidental. Adília y Camões tienen una pasión explícita por el Cristo apasionado, un problema que atraviesa sus obras. Por eso, el Hijo de la Humanidad, en los casos de las dos poéticas aquí contempladas, mediará la relación entre la poesía y el Antiguo Testamento.

Palabras clave: Biblia; Poesía portuguesa; Eclesiastés; Adília Lopes; Camões.

Como indicou Elias Bickerman, o Eclesiastes é um livro estranho. Diz-nos Frederico Lourenço, tradutor da Bíblia grega e amante dela:

Bickerman entende que o pano de fundo contra o qual devemos conceber o surgimento deste livro é o pensamento grego da época alexandrina, com toda 
a carga de pessimismo que lhe era próprio. Nós, leitores da filosofia posterior, não podemos deixar de estabelecer pontos de contato entre o pensamento de Eclesiastes e a grande obra de Arthur Schopenhauer. (2016, p. 107).

Portanto, o texto eclesiástico transita entre a religião e a filosofia, dois campos, a propósito, que não são reciprocamente intransponíveis. A introdução ao livro presente na Bíblia de Jerusalém (que, aliás, não enxerga grande helenismo no texto) sublinha que a obra é de transição: "As certezas tradicionais são abaladas, mas por enquanto nada de seguro as substitui" (2002, p. 1070). Seja como for, o Eclesiastes é considerado um dos livros sapienciais da Bíblia, posto em lugar próximo, em muitas edições, aos poéticos. Nessa imbricação entre poesia e sapiência se encontra Salomão, rei que certamente não escreveu nem o Cântico dos cânticos, nem o Eclesiastes, mas cujo nome é colado à escrita de ambos os livros.

Este texto se propõe visitar o Eclesiastes que tocou duas vozes da poesia portuguesa. Uma, contemporânea, outra, contemporânea também, mas de contemporaneidade menos cronológica. Começo pela primeira, Adília Lopes, para depois chegar à segunda, Luís de Camões. Não é a primeira vez que reflito sobre a relação entre Camões e Adília. O primeiro dos textos que dediquei a essa relação se detinha simplesmente sobre a presença camoniana na obra da autora de Um jogo bastante perigoso. O segundo lia um erotismo muito forte nela e nele, tendo Bocage como terceira presença. E volto a esse diálogo, entendendo-o como profícuo em muitos sentidos. Adília Lopes é autora de um poema cujo título é "Eclesiastes", o que deflagra uma relação clara com o texto bíblico:

\title{
ECLESIASTES
}

"Seulete suy et seulete vueil estre, Seulete m'a mon doulx ami laissie »

Christine de Pisan

\author{
Tempo de foder \\ tempo de não foder \\ saber gerir \\ os tempos compor \\ saber estar sozinha \\ para saber estar contigo
}


ou vice-versa

aqui estão as minhas contas

do que foi

(2009, p. 196)

O diálogo adiliano é explícito com o começo do capítulo 3 do livro do Antigo Testamento, onde se lê:

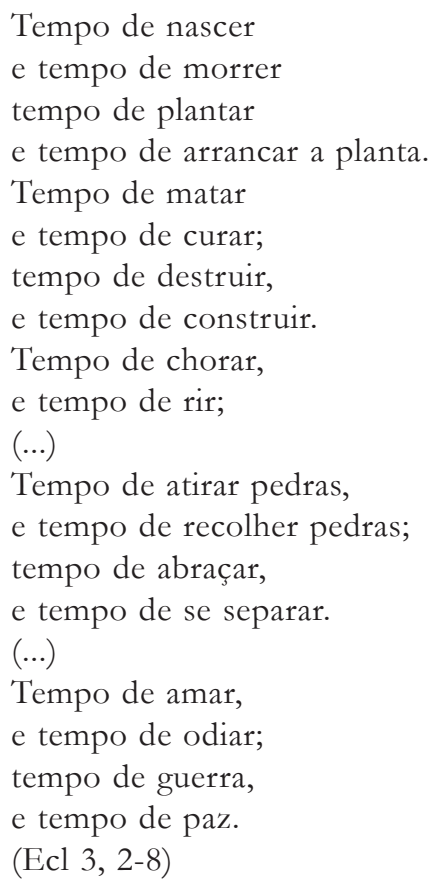

Para ler o poema de Adília Lopes, ou melhor, o diálogo entre o Eclesiastes adiliano e o bíblico, penso imediatamente em Camões, em virtude de um pormenor lateral, mas, quero crer, não insignificante: a violência. Tenho de parar uns instantes nesse pormenor. O mais célebre diálogo da lírica camoniana com o Antigo Testamento são, certamente, as redondilhas que ficaram conhecidas como "Sôbolos rios". Não é apenas o Salmo 137 o texto-fonte do longo poema de Camões; como diversas leituras indicaram, lá está a sombra do Fédon platônico, como ensina Maria Vitalina Leal de Matos, e mesmo de um texto como a Arcadia, de Jacopo Sannazaro. Mas a razão de ser precípua de "Babel e Sião" é o Salmo 137 (136 na Septuaginta), que se 
conclui com uma maldição peculiarmente violenta: "Ó devastadora filha de Babel,/ feliz quem devolver a ti/ o mal que nos fizeste!/ Feliz quem agarrar e esmagar/ teus nenês contra a rocha" (S1, 137, 8-9). Peter Sloterdijk, no seu magnífico Ira e tempo, afirma que a "formulação inicial do Salmo 94, 'Deus, a quem pertence a vingança, aparece’ (...), poderia servir como motivo principal e como guia para uma boa parte do Livro dos Salmos" (2012, p. 114). Mais adiante, escreve o filósofo alemão: "Como a antiga Israel viveu por longos períodos em crônicas tensões de guerra, a sua religião também precisou ser incontornavelmente uma religião do front." (Idem, ibidem).

Cito Sloterdijk para ressaltar que os "nenês" da "filha de Babel" a serem esmagados na "rocha" são mesmo criancinhas, ou seja, não é uma metáfora. Por sua vez, Camões contorna essa tensão de guerra em seu poema, no qual não existe necessariamente vingança, mas ascese - claro, entre o Salmo e Camões há, de fato, Platão e, acima de tudo, Jesus Cristo, o que ameniza notavelmente a ira, palavra de Sloterdijk, que caracteriza muito do Antigo Testamento. Em "Sôbolos rios", quem deve ser jogado na pedra são os "pensamentos" que podem vir a tornar-se viciosos:

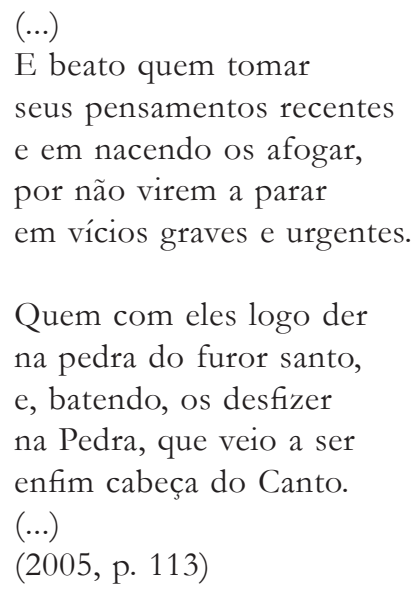

Quem com eles logo der na pedra do furor santo, e, batendo, os desfizer na Pedra, que veio a ser enfim cabeça do Canto.

Ou seja, Babel, em "Babel e Sião", não é um lugar marcado, mas um macrossema para corpo, mundo etc., ou seja, imanência, e não percamos de vista que o desidério desse poema é nada menos que a salvação extramundo. Tudo isso para, voltando a Adília, tentar entender no poema dela um movimento não tão distinto a camoniano, ou seja, uma deslocação da violência que se encontra no texto-fonte. O movimento do "Eclesiastes" 
adiliano é de enxugamento dos tempos ditos na Bíblia; no livro pretensamente salomônico, os tempos se opõem entre vida e morte, criação e destruição, alegria e tristeza, num constructo dicotômico cuja conclusão aparece versículos após o último aqui citado: "E compreendi que não há felicidade para ele a não ser no prazer e no bem-estar durante sua vida. E, que o homem coma e beba, desfrutando do produto de todo o seu trabalho, é dom de Deus." (Ecl 3, 12-13). Não é muito discreto o eco epicurista dessa passagem, a que se seguem novos versos: "Compreendi que tudo o que Deus faz é para sempre./ A isso nada se pode acrescentar,/ e disso nada se pode tirar./ Deus assim faz para que o temam.” (Ecl 3, 14). Suponho, pois, que, além da dimensão de temor que o versículo 14 descortina não figurar claramente no poema de Adília, o que a poetisa explora é, acima de tudo, o jogo de não e sim, a movência imparável do texto bíblico que, não obstante, estagna em seu aspecto dicotômico e, enfim, na impossibilidade de movimento em Deus - "nada se pode acrescentar", "nada se pode tirar".

O que chamei de enxugamento no poema de O peixe na água é o fato de todos os exemplos de alternância temporal que aparecem no capítulo do livro bíblico se reduzirem a dois tempos: "Tempo de foder/ tempo de não foder". É preciso considerar atentamente a epígrafe do poema, vinda da trovadora medieval Christine de Pisan. Essa paragem medieval descortina, não apenas o amor cortês que, à sua maneira, imita Jesus Cristo em termos de adoração e virtude, mas também um feminino que se apresenta enquanto desconcerta a recorrência, na lírica galaico-portuguesa, de vozes líricas femininas nas cantigas às quais correspondem autores homens. Talvez seja forçoso agora dizer que, tanto na poesia de Camões como na de Adília Lopes, Jesus Cristo é mediador, mesmo que não aparecido, dos diálogos dele e dela com o Antigo Testamento - em "Sôbolos rios", claro, Jesus aparece, modificando radicalmente a violência do Salmo 137. Este ensaio não irá fundo na direta presença de Cristo em Camões ou Adília, pois meu problema é pré-cristão; marco esse aspecto, inclusive, para convidar Cristo, ao menos em Camões, muito em breve, noutro(s) trabalho(s).

Pensei em Cristo por causa da Idade Média na epígrafe de Adília, mas tenho de pensar mais detidamente em amor. Dois aspectos marcam a relação da poesia adiliana com a religião, segundo Marcio Cappelli: o jogo, lido pelo ensaísta a partir de Agamben, e a rasura - "os poemas podem ser lidos do ângulo de uma tradição religiosa, porém, borram-na e rasuram-na” (2020, p. 118). Uma das ferramentas que rasuram o Eclesiastes bíblico no adiliano é a epígrafe, e parte de sua anima está em cantar o amor cortês, num feminino 
que efetivamente corresponde a uma poetisa. O problema do feminino é central na relação da obra de Adília Lopes com Deus, como indica Cappelli lendo "Deus é a nossa mulher-a-dias" e sublinhando o "deslocamento da imagem divina masculina mais sedimentada no imaginário cristão ocidental" (Idem, ibidem). Não sabemos quem é o autor do Eclesiastes, identificado como Coélet, filho de Davi - coélet é substantivo comum que indica a pessoa que fala numa assembleia, o que tem a ver, claro, com o título da obra, que significa, literalmente, assembleia, e depois estará na origem da própria ideia de igreja. De todo modo, é muito pouco provável que Coélet seja uma mulher. Assim, a primeira dobra que Adília faz do livro bíblico é encontrá-lo tendo como companhia a lírica medieval de Pisan e enfraquecendo o Deus masculino do imaginário ocidental.

Essa dobra se liga a outra, de que tento me aproximar voltando ao enxugamento que o poema de Adília Lopes realiza, e que, inclusive, reduz a recorrência anafórica eclesiástica, pois apenas dois versos começam por "Tempo de (...)". E é o amor, apenas, o que interessa, nada da violência que participa do texto hebraico e, menos ainda, a impossibilidade de algo ser acrescentado ou tirado da disposição feita por Deus. Pelo contrário: o trabalho adiliano, como indicou Cappelli, é de movimentar o texto religioso, e movimentar o Eclesiastes é retirar dele uma de suas pedras fundamentais. Logo, os dois únicos tempos que o poema apresenta, o de "foder" e o de "não foder", possuem mais plasticidade que os muitos tempos do livro do Antigo Testamento, no qual a alteração é basicamente dicotômica. Penso isso porque noto, entre o foder e o não foder, não apenas a necessidade notável de uma gerência cheia de sabedoria, o que não deixa de estar na Bíblia, mas a solidão. Não me parece exagerado supor que o "saber estar sozinha" é onde se expressa a sabedoria, palavra-chave para Coélet, da voz feminina que, acompanhada da solidão cortês de Pisan, indica que perceber a solidão, sabiamente, seria impossível para o homem que forjou o livro sapiencial, que guarda uma passagem bastante pouco simpática ás mulheres:

E descobri que a mulher é mais amarga do que a morte, pois ela é armadilha, seu coração é rede e seus braços, cadeias.

Quem agrada a Deus dela escapa, mas o pecador a ela se prende. $(\mathrm{Ecl} 7,27)^{1}$

\footnotetext{
Os versículos seguintes relativizam esta passagem misógina, indicando que se trata de uma opinião geral.
} 
Não há qualquer dimensão de pecado no poema de Adília, muito menos, obviamente, associação entre mulher e perdição. Ao conquistar a sabedoria da solidão, o poema encontra a possibilidade de fundação de uma subjetividade, condição sine qua non para o encontro. É curioso observar, num ensaio que procura diálogos de Adília e Camões com o Eclesiastes, que a autora que reuniu sua poesia numa Obra e, anos depois, numa Dobra, justo em seção de poema que conversa com o autor d'Os Lusíadas, escreve algo também da ordem de uma construção subjetiva: "É bom/ tu não seres/ eu/ é bom/ eu ser eu/e tu seres tu" (p. 359). Esse "(anti-Camões)" sugere que os encontros precisam de dois, ainda que o processo de subjetivação de cada um seja pleno trânsito, assim como é de trânsito que se faz, através, talvez, da ponte da solidão, os caminhos e descaminhos entre o "Tempo de foder" e o "de não foder". Passo não mais que de passagem por uns versos importantes de Ruy Belo quando leio essa sabedoria de Adília: "Feliz aquele que administra sabiamente/ a tristeza e aprende a reparti-la pelos dias/ Podem passar os meses e os anos nunca lhe faltará" (2004, p. 159). Ainda que o diálogo beliano mais direto seja com o Evangelho de Lucas, no poema de O problema da habitação habita uma sabedoria triste, não tão distante do que se lê no adiliano. Comentando um Ruy Belo religioso, Marcos Aparecido Lopes faz uma pergunta-chave: "Como definimos Deus se não a partir de nós próprios?" (2011, p. 161).

Marcos lendo o Ruy Belo que me sabe próximo a Adília me faz pensar melhor na subjetivação que tem lugar no poema dela. É claro que Jesus Cristo ajuda imensamente uma relação com Deus que passe, na pessoa humana, pela pessoa humana. Jesus, repito, é presença suposta no poema adiliano, talvez mediador não dito entre a poetisa e o Antigo Testamento, reunião de livros em que não figura Jesus, pois escritos antes dele. É um tema forte para qualquer reflexão cristã, já enfrentado em inúmeros comentários, o quanto de continuidade e o quanto de ruptura há entre Antigo e Novo Testamento. Mas Jesus não figura nesse poema de Adília, o que se torna ainda mais relevante se pensarmos na quantidade de vezes em que ela convoca o Filho da Humanidade - para dialogar com ele, refigurá-lo, acarinhá-lo. Pensando nisso, entendo que a subversão do "Eclesiastes" de Adília também reside na construção de uma subjetividade que efetivamente se põe na relação com Deus, definindo-O, para usar a reflexão de Marcos Lopes, enquanto se define a si mesma.

É considerando essa construção que leio versos tão significativos como "aqui estão as minhas contas/ do que foi": troca de pele, metamorfose, acerto. 
Intuo que seja nesse lugar que habita o Deus desejado pela autora, ou seja, um Deus que cambia de pele, tão presente como pôde ser o Deus do Antigo Testamento, mas tão amoroso como o que Jesus encarnou. Há também um sentido de conta que me sabe muito adequado em Adília Lopes. Encontro num poema de $A$ continuação do fim do mundo, de 2000, os seguintes versos: "A obra de arte/ não é um ajuste/ de contas/ é um ajuste de cantos (...)" (p. 269). O poema dialoga com "A abóbada", famoso conto de Alexandre Herculano, cuja narrativa passeia por idas e vindas da construção da Sala do Capítulo do Mosteiro da Batalha. Pensando em arquitetura, é preciso ajustar cada canto da construção. Pensando em poesia, que é, sabemos desde antes de Camões, canto, é preciso que as muitas vozes que querem dialogar ao longo da história dessa arte se ajustem, mesmo que em situação de atrito. Portanto, lendo-o com o recém-citado poema, cronologicamente posterior, o "Eclesiastes" adiliano expõe suas contas para afinar seu canto, mesmo que lhe pareça haver muita coisa desafinada do livro bíblico.

A violência é uma dessas desafinações? O Eclesiastes do assim chamado Coélet, assim como o Salmo 137 e muito mais do irado, para falar com Sloterdijk, Antigo Testamento, tem momentos de violência. Aberto que é, como não poderia, historicamente, deixar de ser, à ideia de guerra, o livro bíblico me faz meditar sobe a violência na poesia de Adília Lopes. Antes de mais, é unânime na crítica adiliana a noção de que sua obra fala da dor - com ironia, muitas vezes, mas sem cair no cinismo. O corpo em Adília Lopes sofre experiências de opressão e é atacado em vários flancos; os atacantes atendem por capitalismo, machismo, misoginia etc. Mas certo poema me faz olhar algo da ordem da violência nessa poetisa de modo singular:

A vida
é luta
e eu gosto assim

Só da luta

da noite

com o dia

nasce o dia

Só da luta

do dia

com a noite

nasce a noite (p. 606) 
O poema está em Caderno, de 2007, sendo, portanto, bastante posterior a "Eclesiastes". Penso em Heráclito, segundo quem "da luta dos contrários nasce a mais bela harmonia" (Apud: BORNHEIM, 2001, p. 36). O présocrático é anterior a Coélet, e não é, claro, hebraico. Talvez ele me ajude a entender a razão por que a poesia de Adília Lopes acolhe uma violência, no mínimo uma luta, mas recusa o que há de brutal no pólo, para usar palavra camoniana, descontente do Eclesiastes. Talvez seja adequado dizer também que Adília não poderia jamais cultivar a violência em sua poesia porque entende muito bem de dor, ou seja, do resultado deletério da violência. Noutro ensaio que escrevi sobre a poetisa, rocei também a sabedoria. Penso eu, lá, num corpo feminino maltratado e posto em situação dolorosa, e, a certa altura, escrevo: "é numa aprendizagem dolorosa com e pelo outro que se instaura no sujeito algum tipo de saber, muitas vezes próximo de uma espécie de sabedoria." (2011, p. 138). Esse texto tem guerra no título, referindo-se especialmente a uma guerra contra o mundo que é, em verdade, guerra de mera sobrevivência no mundo. Se tem vontade de potência a poesia de Adília Lopes, não tem qualquer vontade de poder, pois, no tempo que a poetisa ocupa e no qual formula seus versos não incombatentes, poder raramente deixa de equivaler a opressão. O lugar adiliano não é, nem poderia ser, o do opressor. Muito pelo contrário, a poesia de Adília Lopes é frequente denúncia da opressão, especialmente em seus poemas mais diretamente políticos.

Este ensaio agora deve atravessar a ponte de "contas" (não de tédio), se eu entender essa palavra no seu sentido, não de cálculo, nem de dívida, mas do pequeno material que compõe, por exemplo, colares, que conduz do Eclesiastes de Adília Lopes ao de Camões. Ajuda-me a construir a ponte, amolecer a ponte, uma afirmação de Silvina Rodrigues Lopes:

Enquanto ficção-figuração, o texto deixa de ser o lugar em que o sujeito se confronta com a desmesura do Absoluto, para ser o lugar da sua dispersão, criação do inacabado, que é movimento e põe em movimento: o gesto instaurador da escrita-figuração não se subordina à vontade unificadora de um sujeito, mas faz coincidir a sua forma - a composição do texto, a sua sintaxe deformante, o seu estilo - com um efeito de inacabamento. (2019, p. 60).

É lugar-comum ler Camões de maneira historicista, que muitas vezes ata o poeta a seu tempo - e o tempo desse poeta é mais que um tempo, é muitos. Contrapõe-se a isso o que já vem se tornando também um lugarcomum: a leitura que nos cabe fazer da poesia de Camões deve ser eivada 
de contemporaneidade, dada a contemporaneidade que podemos divisar na própria obra camoniana. Digo isto apenas para situar que, num diálogo do autor d'Os Lusíadas com Adília Lopes, diferenciações de caráter meramente epocal entre os dois autores, ainda que existam, e passarei por elas, talvez não sejam o mais produtivo. Lendo Silvina Lopes e pensando em Adília, torna-se ainda mais legível a construção subjetiva que "Eclesiastes" propõe, reconhecendo que aquela voz é inacabada e não possui, sequer pretende, qualquer "verdade unificadora".

Já se eu optar por ler o que aqui me interessa em Camões a partir do que escreveu a notável ensaísta, posso começar a pensar na enorme dificuldade que a obra camoniana enfrentou para formular o Absoluto, e imagino o quanto isso terá sido doloroso para um poeta daquele tempo. Se Camões escrevesse no século XIX, talvez pudesse lidar melhor com o Absoluto à maneira romântica. Mas Camões não é um poeta romântico, apesar das frestas que permitiram a muitos setecentistas e oitocentistas, de Schlegel a Garrett, de Fichte a Carolina Michaëlis e ao primeiro Machado de Assis, adotar o cantor (e descantor) de Vasco da Gama como interlocutor privilegiado, até mais, como alma gêmea. Aspecto central na relação de Camões com a fé é uma espécie de choque entre uma imensa paixão por Jesus Cristo, uma inegável aderência a princípios cristãos mas alguma coisa que escorrega disso - leituras como a de Jorge de Sena e Fiama Hasse Pais Brandão entendem que o poeta esteve mais perto do judaísmo (Sena pensa-o como alumbrado, Fiama como quase um cabalista) do que gosta de admitir, no que toca a um nome que a cultura sempre tentou oficializar, o catolicismo português.

Posso acrescentar a isso o que uma leitora como Maria Vitalina Leal de Matos entende como pessimismo em Camões, e que eu posso entender como desespero, palavras que dão conta da intensidade com que o poeta experienciou o que podemos chamar, com ele, de desconcerto. Ficará tudo mais concreto nessa chegada a Camões com a primeira estrofe da magnífica Canção X, poema que pode ser considerado um dos testamentos do poeta:

Vinde cá, meu tão certo secretário

dos queixumes que sempre ando fazendo, papel, com que a pena desafogo!

As sem-razões digamos que, vivendo, me faz o inexorável e contrário Destino, surdo a lágrimas e a rogo.

Deitemos água pouca em muito fogo; 
acenda-se com gritos um tormento que a todas as memórias seja estranho.

Digamos mal tamanho

a Deus, ao mundo, à gente e, enfim, ao vento,

a que já muitas vezes o contei, tanto debalde como o conto agora; mas, já que para errores fui nascido, vir este a ser um deles não duvido.

Que, pois já de acertar estou tão fora, não me culpem também, se nisto errei.

Sequer este refúgio só terei:

falar e errar sem culpa, livremente.

Triste quem de tão pouco está contente! (2005, p. 223)

Será o testamento algo da ordem do que Adorno entende como estilo tardio, ideia desenvolvida, décadas depois, por Edward Said? Nesse, talvez, estilo tardio camoniano, há realmente um problema de tempo; Said, lendo Adorno, insiste não apenas na morte como componente central do estilo tardio, mas na negatividade, ou seja, "um desafio espinhoso, árduo e incessante" (2009, p. 32). Poder-se-ia pensar em estilo tardio na própria escrita do livro bíblico do Eclesiastes? Talvez não, posto que não conhecemos outras obras daquele autor, ou melhor, daquela assinatura, Coélet. Mas, em Camões, um poema como a Canção X, árduo e espinhoso, parece que chegou tarde demais. Não o diz um poeta cheio de sabedoria, pelo contrário, pois sua parceria com o papel só pode trafegar pelas "sem-razões". Essa composição vocabular é espantosa, pois a uma das palavras-obsessão de um ocidente bêbado de Renascimento, ou seja, maneirista mas ainda pretensamente pósmedieval, o poeta adiciona um prefixo de negação. O recurso é comum à filosofia desde a aletheia grega, que, pela negativa, abre um mundo de positividade, a verdade, em grande medida. Portanto, cabe perguntar: que positividades são abertas nas "sem-razões" que o poema dirá? O mal, sem dúvida, é uma delas, mas o mal é já uma contrariedade. Estamos, logo, diante de um poema que se faz na completa negatividade, intensificada na estranheza desse "tormento" a "todas as memórias" - que ancoragem, em que passado?

Aqui, nesse poema que muitos lerão como pessimista, para recuperar termo do comentário de Elias Bickerman ao Eclesiastes, o primeiro afastamento do livro do Antigo Testamento é mesmo este: nenhuma sabedoria. Claro que existe alta performatividade nisso, posto que o estilo tardio só é manifestado por quem muito viveu, e existirá, talvez, sabedoria 
na confissão sábia da não sabedoria. De qualquer modo, há a negatividade, tão aguda que o poema entende a quase impossibilidade de ser recebido. Um desses destinatários "surdo a lágrimas e a rogo" é Deus, que participa de elenco onde figuram também o "mundo", a "gente" e o "vento". A não esperança de que exista satisfatória recepção lembra-me versos de outra Canção camoniana, a II: "A instabilidade da Fortuna,/ os enganos suaves d'Amor cego,/ (...)/ direi, por dar à vida algum sossego;/ que, pois a grave pena me importuna,/ importune meu canto a toda a gente" (2005, p. 205). Fato é que, com Deus participando da lista de "gente surda e endurecida" (Lus, X, 145, 4) - cheiro, vago, de algo da ordem da predestinação? -, pouco de transcendência religiosa resta ao poeta, que investe, a partir de sua desesperança, no erro do erro: "Sequer este refúgio só terei: falar e errar sem culpa, livremente./ Triste quem de tão pouco está contente”. Na Canção II, talvez seja o erro o que possibilite ao poeta a mera hipótese de importunar com seu canto, o que é, para ouvidos que muito aprenderam com a Antiguidade, inversão acentuada.

O Eclesiastes, como indicou Bickerman, é um livro estranho. A primeira aparição de Deus, discreta, é apenas no final do primeiro capítulo: "Eu, Coélet, fui rei de Israel em Jerusalém. Coloquei todo o coração em investigar e em explorar com a sabedoria tudo o que se faz debaixo do céu. É uma tarefa ingrata que Deus deu aos homens para com ela se atarefarem" (Ecl, 2, 12-13). Depois, Deus precisará esperar dezenas de versículos para voltar a ser referido, agora sim de modo mais significativo: "Eis que a felicidade do homem é comer e beber, desfrutando do produto do seu trabalho; e vejo que também isso vem da mão de Deus, pois quem comerá e quem se alegrará, se isso não vier dele?” (Ecl, 2, 24-25). A sabedoria, nesse livro sapiciencial, é cheia de ambigüidade: tem a ver com a "tarefa ingrata", é algo dado por Deus ao "homem do seu agrado" $(2,26)$ mas, em rigor, é causa de dor: "Muita sabedoria, muito desgosto;/ quanto mais conhecimento, mais sofrimento.” $(1,18)$.

Talvez eu esteja querendo dizer que Deus, em Camões e no Eclesiastes, é coadjuvante, luxuosíssimo, mas não protagonista. O encerramento do livro bíblico, seu epílogo, é curioso:

Além de ter sido sábio, Coélet também ensinou o conhecimento ao povo; ele ponderou, examinou e corrigiu muitos provérbios.

Coélet procurou encontrar palavras agradáveis e escrever exatamente palavras verdadeiras.

As palavras dos sábios são como aguilhões e como estacas fincadas pelos 
autores das coletâneas: é o dom de um pastor único.

Além disso, meu filho, fica atento: fazer livros é um trabalho sem fim, e muito estudo cansa o corpo.

Fim do discurso. Tudo foi ouvido. Teme a Deus e observa seus mandamentos, porque aí está o homem todo:

Sim, Deus fará toda obra vir ao julgamento, tudo o que ela contém de bom ou mau. (Ecl, 12, Epílogo)

Posso pensar agora numa das razões por que não há sabedoria no poema, que, nesse ponto, se distingue do texto com o qual dialoga: não cabe à poesia ser sábia, o que a afasta, talvez por vocação, do texto religioso. Não obstante, o Deus coadjuvante do final do Eclesiastes me lembra o encerramento de um famoso soneto camoniano, cujo incipit é "Verdade, Amor, Razão, Merecimento". Após treze versos fundamente reflexivos e espantados diante do desconcerto do mundo, surge o verso final: "mas o milhor de tudo é crer em Cristo" (2005, p. 199). Já escrevi que Cristo não é Deus, ainda que O seja, em Camões e em Adília; não obstante, a função Cristo que encerra o soneto me lembra o Deus que encerra o livro do Antigo Testamento, que aparece no final do último capítulo como, sem qualquer ironia, um Deus ex machina, que resolve a equação sem que esteja nela submergido - o que, por sua vez, me lembra versos importantes do Canto $\mathrm{X}$ d'Os Lusíadas, surgidos pouco após Thetys mostrar a Vasco da Gama a Máquina do Mundo: “(...) mas o que é Deus, ninguém o entende,/ Que a tanto o engenho humano não se estende.” (X, 80, 7-8).

Evidente, por sua vez, é que Camões se encontra com Coélet na detecção da vaidade: pouco se retira da sabedoria, pouco se retira do amor, tudo passa, mesmo certa sábia, adiliana, consciência, triste, do tempo de cada coisa. Lembrome agora do começo da fala do Velho no Canto IV, o Velho, esse sim, sábio, "Cum saber só de experiências feito" (IV, 94, 7), que acusa a vaidade duas vezes apenas nos dois primeiros versos que diz: “Ó glória de mandar, ó vá cobiça/ Desta vaidade a que chamamos Fama" (IV, 95, 1-2). Costuma-se ler essa dupla ocorrência de vaidade como uma crítica, dura, ao projeto expansionista. Sem dúvida. Mas não podemos pensar também que o projeto é uma empresa vã como seria qualquer outra? É certo que o Velho, investido de teluridade e não desinvestido de perspectiva histórica, sugere que uma política mais eficiente passaria pelo Norte da África, o que mostra que alguma não vaidade ele via na história. Contudo, vejo-me atraído a considerar uma espécie de estilo tardio nesse Velho, que tem no pessimismo uma funda marca. 
Na Canção X, não há vocábulo que mais se acerque da vaidade segundo o Eclesiastes que "debalde": de nada adianta o canto, seu engenho e arte, se seu exercício é vão, debalde: "fazer livros é um trabalho sem fim, e muito estudo cansa o corpo". Ocorre-me agora um momento central do Canto X d'Os Lusíadas, a penúltima estância do poema, quando Camões volta a se dirigir, "debalde", ao rei de Portugal, D. Sebastião, esboçando uma espécie de autorretrato:

Mas eu que falo, humilde, baxo e rudo,

De vós não conhecido nem sonhado?

Da boca dos pequenos sei, contudo,

Que o louvor sai às vezes acabado.

Nem me falta na vida honesto estudo,

Com longa esperiencia misturado,

Nem engenho, que aqui vereis presente,

Cousas que juntas se acham raramente. (X, 154)

Segundo o livro bíblico, todo esse estudo, todo o engenho a toda a arte, só cansam, talvez porque, no fim das contas, possa aparecer Deus e resolver o problema. Isso tem algo a ver, apesar da modificação extrema que Jesus Cristo impôs à religião que o gerou (tão extrema que gerou outra religião), com a teologia medieval; segundo Bertrand Russell, Tomás de Aquino, "antes de começar a filosofar, já sabe a verdade; está declarada na fé católica. Se encontra argumentos racionais para algumas partes da sua fé, tanto melhor; se não, basta-lhe regressar à revelação" (Apud DIAS, 2019, p. 48). Não havia ainda a revelação Cristo para Coélet, muito menos fé católica, mas ele já dispunha da possibilidade de regressar a Deus na falta de qualquer argumento racional, quer dizer, sábio. É nisso que Camões não se sustenta. $\mathrm{Na}$ estrofe 154 do Canto $\mathrm{X}$, nenhuma referência à fé, nem como crença, nem como moeda que pudesse valorizar o poeta aos olhos de alguém que é rei por direito divino, ainda mais D. Sebastião, cuja existência garantia, quase maravilhosamente, a manutenção da independência portuguesa.

Em Camões, isso tem a ver com uma presença excessiva de Cristo e uma ausência notável de Deus. Adília Lopes agora me ajuda a entender o Jesus de Camões: no "Ecleasiastes" adiliano, foda, amor cortês e administração do tempo se encontram, sugerindo o Cristo que tantas vezes aparece explicitamente na obra da poetisa. Pensando assim, Cristo, em Camões, é mais amor que salvação, mais espelho que santidade, não obstante 
o inevitável "Sôbolos rios", no qual Cristo é o que pode afiançar a vida eterna. Quiçá não seja despropositado visitar outro livro bíblico para cogitar o absurdo e o desconcerto. O livro de Jó, outro livro sapiencial, é, pelo menos para mim, dos mais estranhos de toda a Bíblia. É dele que vem o motivo de um importante soneto camoniano, cujo primeiro quarteto é: "O dia em que eu nasci, moura e pereça,/ não o queira jamais o tempo dar,/ não torne mais ao mundo, se, se tornar,/ eclipse nesse passo o sol padeça." (2005, p. 182). Assim é a primeira fala de Jó em seu livro: "Pereça o dia que me viu nascer,/ a noite que disse: 'Um menino foi concebido!'/ Esse dia, que se torne trevas,/ que Deus do alto não se ocupe dele,/ que sobre ele não brilhe a luz!" (Jó, 3, 3-4). Ainda que em plena negatividade, Deus é citado por Jó. Já no soneto camoniano, não obstante a ambiência apocalíptica, Deus não é nomeado uma vez sequer, muito menos qualquer hipótese salvífica.

Jó e Eclesiastes têm em comum, para deleite de Camões, deflagrações do desconcerto. No entanto, e é isso o que me faz considerar Jó muito estranho, há, muito antes do final feliz do livro, um motivo muito pouco nobre para a provação imposta àquele "homem íntegro e reto, que temia a Deus e se afastava do mal" (Jó 1,1). Lê-se no capítulo 1:

No dia em que os Filhos de Deus vieram se apresentar a Iahweh, entre eles veio também o Satã. Iahweh então perguntou ao Satã: "De onde vens?" "Venho de dar uma volta pela terra, andando a esmo", respondeu o Satã. Iahweh disse ao Satã: "Reparaste no meu servo Jó? Na terra não há outro igual; é um homem íntegro e reto, que teme a Deus e se afasta do mal." O Satã respondeu a Iahweh: "É por nada que Jó teme a Deus? Porventura não levantaste um muro de proteção ao redor dele, de sua casa e de todos os seus bens? Abençoaste a obra das suas mãos e seus rebanhos cobrem toda a região. Mas estende tua mão e toca nos seus bens; eu te garanto que ele te lançará maldições em rosto." Então Iahweh disse ao Satã: "Pois bem, tudo o que ele possui está em teu poder, mas não estendas tua mão contra ele.” $\mathrm{E}$ o Satã saiu da presença de Iahweh. (Jó, 1, 6-12)

Como as provações do Satã - destruir tudo o que o homem possui e matar suas filhas e filhos - não levam Jó a qualquer blasfêmia, Iahweh, no consílio seguinte, permitiu que o provocador fizesse adoecer o homem já despossuído: o Satã "feriu Jó com chagas malignas desde a planta dos pés até o cume da cabeça." (Jó, 2, 7). Satã, no livro, não é nome próprio, mas significa algo como o adversário, um ser, superior ao humano, que provoca (por isso o termo que usei linhas acima) Deus e duvida da eficácia da Sua 
criação. ${ }^{2}$ É pessimista, talvez, esse Satã, o que o aproxima estranhamente do Coélet do Eclesiastes: este insiste na vaidade da ação humana, o outro, de certo modo, também, pois não entende a humanidade vocacionada para nada muito significativo. ${ }^{3}$ Já o Deus falante do Livro do Jó (falante como em muitos livros do Antigo Testamento, enquanto é silente no Eclesiastes), tem em seu servo uma garantia da aliança e da fé, um, por assim dizer, produtor de sentido. Isso está ao fundo de Seu gesto que faz desse livro, para mim, muito estranho: a mistura de ostentação e infantilidade que $\mathrm{O}$ leva a atiçar o Satã, atiçado por este. É Iahweh quem provoca seu adversário ao lhe mostrar, ostensivamente, o sucesso da fidelidade de Jó, como se, inconscientemente, fosse Ele quem quisesse usar o servo para demonstrar Seu poder, inclusive porque o pluripoderoso Iahweh pode, no final de tudo, ofererer a Jó uma espécie de compensação - ainda que não devolva as filhas e filhos mortos pelo anômalo (ou nem tanto?) acordo feito com o Satã, o que enche de sombras o bappy end do livro. ${ }^{4}$

2 Acho muito instigante que, no final do Canto I d'Os Lusíadas, a instância que bagunça a vida humana, mais ou menos como o Satã de Jó, é o Céu: "Onde pode acolher-se um fraco humano,/ Onde terá segura a curta vida,/ Que não se arme e se indigne o Céu sereno/ Contra um bicho da terra tão pequeno?” (I, 106, 5-8). Há leitores que entendem esse Céu como o cristão; já outros, dada a presença forte da mitologia no Canto I, como o Olimpo. Mas a ambiguidade é imensamente provocadora. Nesses versos, o divino, ou o que transcende o humano, tem uma força altamente deletéria.

3 Uma pouquíssima, quase nula, potência de intervenção do agir humano no mundo me faz recordar um poema de Alberto Caeiro, o XLII d'O guardador de rebanhos "Passou a diligência pela estrada e foi-se;/ E a estrada não ficou mais bela, nem sequer mais feia./ Assim é a acção humana pelo mundo fora./ Nada tiramos e nada pomos; passamos e esquecemos;/ E o sol é sempre pontual todos os dias.” (2006, p. 92). É tentador trazer o heterônimo pessoano a este ensaio, mas, por razões de tempo, tamanho e economias diversas, deixo-lhe ao menos esta nota. Não resisto a comentar, modestamente, que o claro diálogo do poema caeiriano com o Eclesiastes tem "o sol" como elemento pertubador do pessimismo, posto que a pontualidade solar que ali aparece produz algum sentido, ainda que não humano - e, justamente porque não humano, considerando o anti-humanismo de Caeiro, ilumina alguma coisa no mundo. Pode-se dizer que a luz do sol também é vã, mas apenas para o homem; quando este, que apenas passa e esquece, nada põe e nada tira, deixa de ser medida para todas as coisas, a própria ideia de vaidade deixa de fazer sentido, ou adquire um inusitado não sentido.

4 Iahweh está claramente se autoafirmando ao provocar o Satã, oq eu fica mais claro quando lembramos o Jesus que, no deserto, como relatam os evangelhos sinópticos, não cai em nenhuma das armadilhas do adversário. Se a postura do Deus-Homem fosse semelhante à do Deus do Antigo Testamento, ele certamente sairia voando diante de uma provocação como "Se és Filho de Deus, atira-te para baixo." (Mt, 4, 6). 
É claro que não se pode perder de vista, como escreveu Sloterdjik, que o Antigo Testamento tem uma dimensão de combate, e talvez Iahweh não pudesse ter uma altivez que só se oferece a um deus sem nacionalidade. Mas o que me interessa camonianamente nesse livro é o desconcerto, que só existe no entendimento de Jó: para ele, seu destino é absurdo, o que assinala a seus olhos a vaidade de todos os gestos humanos, mesmo os cheios de fé. Digna de nota é a vaidade também dos diálogos de Jó com seus amigos pretensamente sábios, que atacam os alvos errados para entender a miséria do servo de Iahweh. O soneto de Camões, repito, recupera do Livro de Jó apenas a primeira intervenção do protagonista, o poema cujo verso equivalerá ao incipit camoniano, e ali fica. Não há, portanto, nem um Satã a mover as peças desse tabuleiro catastrófico, nem um Iahweh mais provocador que o adversário a esfregar-lhe na cara o êxito de seu servo, muito menos consolação ou compensação no final de tudo. Há é um desconcerto de origem incerta. O terceto final - "Ó gente temerosa, não te espantes,/ que este dia deitou ao mundo a vida/ mais desgraçada que jamais se viu!” (2005, p. 182) - nada resolve, não localiza qualquer agente da desgraça, apenas aponta o contrário da graça, como se não houvesse agente capaz de fornecer graça alguma, seja ele Deus, seja ele, por exemplo, a Leanor daquelas redondilhas inesgotáveis - "Chove nela graça tanta/ que dá graça à fermosura; vai fermosa, e não segura" (2005, p. 56) -, que recupera para a beleza e o desejo os poderes da graça. No poema, portanto, nem graça salvífica, nem amorosa, nenhuma beleza.

Desse Apocalipse sem graça nem revelação volto ao erro, palavra-chave em Camões, condição da própria prática da poesia. ${ }^{5}$ Meditar sobre o erro com o Eclesiastes dá relevo interessante ao que esse livro diz dos livros: "fazer livros é um trabalho sem fim, e muito estudo cansa o corpo". Invertendo um pouquinho a direção desse infinito, uma das metáforas mais extremas para erro, fracasso e trágico em Camões nunca foi escrita, e é o que é justo por nunca ter sido escrita. Refiro-me às duas estâncias finais d'Os Lusíadas, vista por alguns leitores como capitulação de um poema que se acercou de uma vontade de não guerra à inevitabilidade bélica, de espírito quase cruzadista, mas que eu vejo como cumprimento, pelo incumprimento, do trágico:

Alguém mais audacioso que eu poderia pôr em perspectiva o erro enquanto errância em Camões ao movimento do Satã, que anda a esmo no Livro de Jó. Uma abordagem assim ganharia grande fôlego com a convocação do mais simpático Satã da história da literatura, o de Milton no Lost Paradise. 
Pera servir-vos, braço às armas feito;

Pera cantar-vos, mente às Musas dada;

Só me falece ser a vós aceito,

De quem virtude deve ser prezada.

Se me isto o Céu concede, e o vosso peito

Dina empresa tomar de ser cantada,

Como a pressaga mente vaticina,

Olhando a vossa inclinação divina,

Ou fazendo que, mais que a de Medusa,

A vista vossa tema o monte Atlante,

Ou rompendo nos campos de Ampelusa

Os muros de Marrocos e Trudante.

A minha já estimada e leda Musa

Fico que em todo o mundo de vós cante

De sorte que Alexandro em vós se veja,

Sem à dita de Aquiles ter enveja. (X, 155, 156)

Nesses 16 versos, o que menos vejo é o chamamento à guerra - ele está lá, mas meus olhos míopes veem melhor outra coisa. Pode me interessar o chamamento como gesto de intervenção, mas o que me interessa mesmo é a promessa: se "o vosso peito/ Dina empresa tomar de ser cantada", "A minha já estimada e leda Musa/ Fico que em todo o mundo de vós cante". Haver alguns versos entre o começo e o final dessa construção pode merecer estudo, que não faço aqui. Apenas martelo naquilo que separa, na perspectiva de Camões, um texto poético de um texto santo, que é a inevitabilidade do erro, em diversas dimensões, no primeiro desses tipos de texto. ${ }^{6} \mathrm{O}$ trágico, no final d'Os Lusíadas (poema, aliás, de alma trágica), é a promessa não cumprida do novo épico. A lusitana tragédia histórica do desaparecimento de

6 O que afirmo é problemático: não haverá de existir alguma sacralidade na poesia? Para não dedicar muitas linhas a isso, apenas transcrevo algo que Jorge de Sena escreveu sobre Faria e Sousa, o infatigável comentador barroco de Camões, e sua perspectiva sobre o épico camoniano: “Às vezes, poderá parecer que, ao aplicar a Os Lusíadas os métodos de exegese que se usavam para todos os textos sagrados, ele está a ser ingénuo ou a tomar-nos por tolos. Mas sucede que, para Faria e Sousa, Os Lusíadas eram duplamente 'sacros', ou mesmo triplamente: por serem uma afirmação portuguesa no mais alto nível da criação poética, por serem uma criação poética do mais alto nível, e por ele adivinhar no autor e na obra a firme intenção estrutural de colocar a liberdade da criação poética no plano do 'sagrado', isto é, no plano do que significa e revela das correlações terríficas entre a história e o estar-se nesse mundo.” (Sena, 1980, p. 200, 201) 
D. Sebastião é parte disso, mas fato é que não há novo livro, e o "sem fim" que se lê no Eclesiastes ganha uma dimensão de enorme fracasso.

Desta conversa entre Adília e Camões, tendo como lugar de encontro o Antigo Testemento, algumas palavras saem voando. Uma delas é sabedoria, pelo sim e pelo não. Mas estimo acalentar outra, mais esquiva, mas que certamente agradaria a poetisa e o poeta: insubordinação. As escritas poéticas de Adília e Camões realizam um notável movimento de insubordinação, mesmo que, muitas vezes, ela e ele entendam que o que resta de sabedoria à poesia por vezes tenha de conspirar para a resignação, mas uma resignação trágica - ou o que Maria Vitalina Leal de Matos, ecoando Eugenio Garin, chama de "lucidez trágica" (2011, p. 74) em Camões. A solidão do desterro tantas vezes cantado por Camões encontra um eco inesperado em versos do "Eclesiastes" adiliano: "saber estar sozinha/ para saber estar contigo/ ou vice-versa". Essa solidão é mais um traço que revela o quanto Jesus Cristo é lugar de identificação para ambos, posto que o Filho da Humanidade é solidão e também agonia, e, por isso, subordinação a seu destino trágico mas insubordinação a tudo o mais - ao dinheiro, ao judaísmo etc. Miguel de Unamuno entendia o cristianismo, ou melhor, a fé na cristandade, como uma prática necessariamente individual, em relação agônica com a própria história.

É dentro dessa solidão, dessa insubordinação, amiga de Cristo inclusive o do "Eli, Eli, lamá sabachtáni?" (Mt, 27, 46) de Mateus - que Adília e Camões acertam as contas, os cantos, com o tempo e as sem razões, na construção de uma sabedoria impossível. Seus textos, inacabados, como nos ensinou Silvina R. Lopes, ou mesmo nonatos, como o segundo épico camoniano, perfazem o trabalho sem fim que é o fazer livros, poemas, e dizê-los ao menos “a Deus, ao mundo, à gente e, enfim, ao vento”.

\section{Referências}

BELO. R. Todos os poemas. 2. ed. Lisboa: Assírio \& Alvim, 2004. v. I.

Bíblia de Jerusalém. Dir. P. Bazaglia, Coor. J. Bortolini, G. S. Gorgulho, I. Storniolo, A. F. Anderson. Paulus, 2002.

BORNHEIM, G. A. (Org.). Os filósofos pré-socráticos. 11. ed. São Paulo: Cultrix, 2001. CAMÕES, L. Os Lusíadas. Ed. E. Paulo Ramos. Porto: Porto Editora, 1978.

Rimas. Ed. A. J. da C. Pimpão. Coimbra: Almedina, 2005.

CAPPELLI. M. O sublime no cotidiano: reescrituras de Cristo na poesia de Adília Lopes.

Teoliterária - Revista de Literaturas e Teologia. n. 10, 2020. pp. 112-129. 
DIAS, S. Anti-doxa - a filosofia na era da comunicação. Lisboa: Documenta, 2019.

LEAL DE MATOS, M. V. Camões: sentido e desconcerto. Coimbra: Centro Universitário de Estudos Camonianos, 2011.

LOPES, A. Dobra - poesia reunida. Lisboa: Assírio \& Alvim, 2009.

LOPES, M. A. A missão de Ruy Belo. In. AlvES, I.; MAFFEI, L. (Org.). Poetas que interessam mais - Leituras da poesia portuguesa pós-Pessoa. Rio de Janeiro: Azougue, 2011. pp. 157-168.

LOPES. S. R. A anomalia poética. Belo Horizonte: Chão da Feira, 2019.

LOURENÇO, F. O livro aberto - leituras da Bíblia. Rio de Janeiro: Oficina Raquel, 2017.

MAFFEI, L. No corpo e na palavra, uma cotidiana guerra em Adília Lopes. In. PADILHA, L.; SILVA, R. F. (Org.). De guerras e violências: palavra, corpo, imagem. Niterói/ RJ, Editora da UFF, 2011. pp. 131-143.

PESSOA, F. Poemas completos de Alberto Caeiro. Ed. J. G. Simões, Maria Aliete Galhoz. Rio de Janeiro: Nova bFronteira, 2006.

SAID. E. W. Estilo tardio. Trad. S. Titan Jr. São Paulo: Companhia das Letras, 2009.

SENA, J. Faria e Sousa, Prefácio de Os Lusíadas. In. Trinta anos de Camões (1948-1978) estudos camonianos e correlatos. Lisboa: Edições 70, 1980. pp. 274-285.

SLOTERDIJK, P. Ira e tempo: ensaio político-psicológico. Trad. M. Casanova. São Paulo: Estação Liberdade, 2012.

UNAMUNO, M. La agonía del cristianismo. 9. ed. Ed. V. Ouimette. Madrid: Esparsa Calpe, 2008.

Submetido em: 30-9-2020

Aceito em: 29-11-2020 